\title{
Correction to: Testosterone-mediated activation of androgenic signaling sustains in vitro the transformed and radioresistant phenotype of rhabdomyosarcoma cell lines
}

\author{
Leo Cabistany ${ }^{1}$ (1) $\cdot$ Victor Silveira Coswig ${ }^{2} \cdot$ Rafael Bueno Orcy $^{1} \cdot$ Fabricio Boscolo Del Vecchio $^{1}$
}

Published online: 17 September 2018

(c) Springer-Verlag Italia S.r.l., part of Springer Nature 2018

Correction to: Sport Sciences for Health (2018) 14:433-438
https://doi.org/10.1007/s11332-018-0439-0

Unfortunately, the title of the above mentioned article has incorrectly been published in the original publication. The complete correct title should read as follows.

"Lack of correlation between bloody and salivary lactate in Taekwondo matches"

The original article can be found online at https://doi.org/10.1007/ s11332-018-0439-0.

Leo Cabistany

leocabistany@gmail.com

1 Universidade Federal de Pelotas, Pelotas, Brazil

2 Federal University of Pará, Belém, Brazil 